\title{
USANDO VEÍCULOS ECOLÓGICOS COMO UMA ALTERNATIVA PARA MELHORAR A QUALIDADE DO AR NAS METRÓPOLES IRANIANAS
}

\section{USING GREEN VEHICLES AS AN APPROACH TO IMPROVE AIR QUALITY IN IRANIAN METROPOLISES}

\section{Mohammad Mohajer}

Department of Industrial Management, Science and Research Branch, Islamic Azad University, Tehran, Iran.

Mohsen Gerami Head of Computer and Information Technology Department, ICT Faculty, Tehran, Iran. E-mail: gerami@ictfaculty.ir

\section{RESUMO}

O Irã como país em desenvolvimento está enfrentando uma quantidade excessiva de poluição do ar em suas grandes cidades. Parece que usar veículos elétricos / híbridos é uma solução apropriada, mas qual carro será mais compatível com a sociedade, o ambiente e as pessoas do Irã ainda é vago? Para responder a essa pergunta, projetamos nosso modelo no qual os quatro híbridos mais populares mundialmente / A eletricidade foi analisada com base nas idéias de especialistas. Em geral, é utilizado o método analítico-descritivo, a comunidade da pesquisa inclui todos os especialistas no campo da gestão ambiental e o tamanho da amostra é obtido usando o método objetivo não aleatório (10 especialistas foram questionados) para priorizar entre carros diferentes com base em um método processo analítico de hierarquia. Os resultados mostraram que, com base na perspectiva dos especialistas, veículos totalmente elétricos são preferencialmente mais compatíveis com a situação do Irã do que veículos híbridos. A característica mais significativa que é contribuída para os veículos elétricos é o alto nível de eficiência de combustível e a menor quantidade de poluição atribuída ao seu motor elétrico, o que significa que eles não liberarão nenhuma poluição no ar. Finalmente, com base nos resultados, sugerimos algumas estratégias, entre as quais a substituição de veículos a combustível antigos e de baixa eficiência, aplicando impostos excessivos regularmente.

Palavras-chave: Veículos Elétricos / Híbridos, Poluição do Ar, Transporte Urbano.

\begin{abstract}
Iran as a developing country is facing excessive amount of air pollution in its big cities. It seems using Electric/Hybrid vehicles is an appropriate solution, but which car will be more compatible with Iran's society, environment and people situation is still vague, in order to answer this question, we designed our model in which 4 most globally popular Hybrid/Electric has been analyzed based on experts' ideas. In general, descriptive-analytic method is used, the survey community is included all experts in the field of environmental management and sample size is obtained using non-random objective method (10 experts have been questioned) for prioritizing between different cars based on an analytic hierarchy process. The results showed that based on the experts' perspective, fully electric vehicles are would rather be more compatible with Iran's situation than Hybrid ones. The most significant feature that is contributed to Electric vehicles is about their high level of fuel efficiency and the least amount of pollution attributed to their Electric engine, which means they will release no pollution into the air. We finally based on the results, suggested some strategies, among which replacing old and low efficient fuel vehicles, placing excessive tax on regular.
\end{abstract}

Keywords: Electric / Hybrid Vehicles, Air Pollution, Urban Transportation 


\section{INTRODUCTION}

Air pollution sources are highly diverse, but in general they can be categorized in four groups: mobile transportation(including motorized vehicles, airplanes, trains, ships and other transportation devices), Combustion static (Including the supply of energy and heat for residential, commercial and industrial purposes), Industrial processes (such as chemical industry, metallurgy and oil refineries), Solid waste disposal (including recycling from domestic and commercial uses, coal waste and the residual ash from the burning of agricultural remnants) (FALAHATI et al, 2016). In fact, although there are different sources of air pollution, because of excessive increasing in number of cars and the average of mile travelled by cars, trans, globally transportation is going to be the most significant source in this realm, therefore it is considered as an environmental and hygiene challenging issue (BATTISTA, 2017).

Since 1950 the rate of manufacturing cars has overtaken the population growth rate, it means in 1960 there were 50 million cars for 3.5 billion people, while nowadays there are 600 million cars for 6 billion people (the average of producing 45 million cars per year). Over the past 50 years, mobile sources of pollution have been strengthened overwhelmingly and is considered as an environmental and health threats. It means in majority of cases atmospheric pollutants have been released from cars (ROMERO-RUIZ et al, 2016). As a result of being exposed to air pollution causes a vast variety of diseases, such as lung cancer, stroke, heart disease and chronic bronchitis, for instance in 2013, 5.5 million premature deaths had happed that among which 1 out of ten was contributed to air pollution (HUANG et al., 2016).

Actually, focus on air pollution and rehabilitating policies for Iran has two significant aspects. At first it is crucial to this country for playing is international environmental role (based on the global air pollution research Iran is among ten countries which release majority of atmospheric pollutants and Ozone gases into the air.

Second of all, air pollution has casted Iran in social, economic and health ways, for example 19644 deaths per year are contributed to air pollution which is equal to 28 cases out of 1000 deaths in this country (WORLD BANK, 2016). In table 1, we have presented the number of clean 1 and polluted days in 8 Iranian metropolises in 2017 , based on the density of $2 \mathrm{PM}_{2.5}$ aerosols. These eight

1 Based on an air quality index (AQI), which has some categories including three important groups, first group is clean with 1-100 amount of AQI, the second is unhealthy for sensitive groups the amount of AQI is between 101 and 150 , the third group is unhealthy one $+151 \mathrm{AQI}($ Iran Environmental Organization, 2011).

2 Fine particles with a diameter of $2.5 \mu \mathrm{m}$ or less, this kind of contamination has a lethal impact on human's health because these particles can penetrate the depth of the respiratory system and even the bloodstream. These particles often come out of the exhaust of automobiles, power factories, and industrial activities (World Bank, 2016). 
big cities have resided 34 percent of whole Iran's urban population ${ }_{1}$ and 25 percent of all country's $\operatorname{population}_{2}$.

This population was exposed to polluted air almost 308 days per year, which is equal to 80 percent of all year's days; it means there are only few days which people can be benefited from the clean air (56 days equal to 16 percent of year's days). The situation of air pollution is more crucial in some cities such as Tehran, Isfahan and Shiraz that among which there are least number of days with clean air (almost 20 clean days per year). Due to the described serious air pollution problem 3 and its devastating effects on people health it is necessary for this country to take practical strategies.

Table 1. Iran's metropolises population and air pollution related data

\begin{tabular}{|c|c|c|c|c|}
\hline $\begin{array}{c}\text { Iranian } \\
\text { metropolises }\end{array}$ & $\begin{array}{c}\text { Population } \\
2017\end{array}$ & $\begin{array}{c}\text { Days with severe } \\
\text { effect on people's } \\
\text { health }\end{array}$ & $\begin{array}{c}\text { Days with moderate } \\
\text { effect on people's } \\
\text { health }\end{array}$ & $\begin{array}{c}\text { Days } \\
\text { number } \\
\text { with clean } \\
\text { air }\end{array}$ \\
\hline Karaj & 1.592 .492 & - & 223 & 142 \\
\hline Tabriz & 1.558 .693 & 15 & 281 & 69 \\
\hline Shiraz & 1.565 .572 & 84 & 266 & 11 \\
\hline Tehran & 8.693 .706 & 95 & 252 & 18 \\
\hline Arak & 520.944 & 95 & 131 & 139 \\
\hline Mashhas & 3.001 .184 & 142 & 175 & 44 \\
\hline Isfahan & 1.961 .260 & 226 & 128 & 11 \\
\hline Ahwaz & 1.184 .788 & 245 & 106 & 15 \\
\hline Total & 20.078 .639 & Average & 195 & 56 \\
\hline
\end{tabular}

World Bank, 2017, Iran’s Population Statistics Centere, 2017

Transportation sector is responsible for almost quarter (23\%) amount of whole air pollution globally (LI et al, 2016). Iran's air quality is affecting from different factors such as industrial activities, physical geography (topography and soil texture) and transportation, however based on the scientific research4, the latter factor is responsible for almost half of the amount of air pollution in Iran(Iran Energy Balance Sheet,2015). In two big Iranian cities, which some studies have been carried about the sources of air pollution, it was revealed that transportation and industrial activities are the first and second sources of releasing pollutant into the air (SARKHOSH et al, 2013). Therefore, it is clear that majority of air pollutant and its harmful effects on people's health in Iran's air can be contributed to transportation.

1 Equal to 59164747 people(Iran's population statistics centre,2017)

2 Equal to 79926270 people(Iran's population statistics centre,2017)

3 The level of air pollution in Iran's cities had increased 0.5 percent per year from 1991 to 2014(Iran Energy Balance Sheet,2015)

4 Between 2007 to $2014,55.5$ percent of air pollution was contributed to transportation sector. 
In the realm of economy, there are some surprising date about the amount of fuel which was burned in cars in Iran. In 2014, gas and gasoline consumption in Iran was equal 55070815.91 liters which is equal to 336602.808 million dollars (average value of oil and gasoline in Persian Gulf countries in 2014), almost half of this amount have been used in transportation system. This value of burned gas and gasoline in Iran was equal to 45.3\% of Iran's GDP, which was equal to 742920 million dollars in 2014 (IRAN ENERGY BALANCE SHEET, 2015). The economic aspect of burning fuel in transportation system shows that it consumes a huge amount of the country prosperity, therefore it is necessary to be reconsidered in order to increase the level of efficiency of fuel consumption in transportation system. In real of economy, harmful effect of air pollution on people's health is equal to $2.2 \%$ of Iran's GDP (13 billion dollars which only considered the costs contributed to death number related to air pollution).

Global warming (which imply on increasing the average of the temperature of atmosphere in long term period) is another issue that all countries should feel committed equally about and taking practical actions in order to reduce the pace of this process. Based on the scientific facts, over a 100 period the average of world's temperature has increased by 0.7 degrees Celsius. Almost all of this process (Global Warming) has happened under effects of human activities and emitting gases such as nitrous oxide gas, water vapor, carbon dioxide, methane, and ozone have been created in the atmosphere of the planet. The results of global warming can be seen in hitting storms, fames, floods, climate disordered climate events which all parts of the world will be damaged from them equally. Therefore, in order to increase the global resilience against this phenomenon, many organizations, institutions and commissions have been formed to deal with this situation, in this process many agreements 1 have been between different countries (WANG et al, 2015). On the other hand, Iran is among 10 countries 2 emitted the highest levels of greenhouse gas gases into the atmosphere (ADNAN et al, 2017). Iran's air temperature increased by 1.8 degrees Celsius from 1950 to 2017, which is above the global average temperature of 1.1 degrees Celsius. Iran also experienced an annual growth greenhouse gas emission by $2 \%$, then to top it off in 2017 this country released 41 billion tons of greenhouse gases (FINANCIAL TRIBUNE WEBSITE 3 , 2018). In order to take practical actions such as reducing the level of energy consumption and increasing the efficiency of fuel consumption (in the realm of reducing the pace of global warming), The 21 st Conference of the Parties (COP21)

\footnotetext{
1 Such as Paris Agreement: The Paris Agreement builds upon the Convention and for the first time brings all nations into a common cause to undertake ambitious efforts to combat climate change and adapt to its effects, with enhanced support to assist developing countries to do so. As such, it charts a new course in the global climate effort (UNFCCC Sites and platforms).

2 In the realm emitting $\mathrm{CO}_{2}$ gas, which is one of the most significant types of greenhouse gases, China 27\%, the USA $17 \%$, Russia $5 \%$, India $5 \%$, Japan $4 \%$ emitted this gas of the whole amount of $\mathrm{CO}_{2}$. Also Iran, Germany, South Korea, Canada, Britain and Saudi Arabia each one released $2 \%$ of this gas in 2017(Adnan et al,2017)

3 https://financialtribune.com/articles/environment/76232/iran-greenhouse-gas-emissions-up-3-in-decade
} 
in 2015, proposed some strategies that have the highest potentials of being applied, among which "more producing and using green vehicles "and" a gradual replacing of gasoline / gasoline vehicles with more efficient ones" were the most important strategies (EV, 2016).

Based on what we presented in previous paragraphs, it is clear that harmful effects of air pollution on people's health and the country's prosperity made it necessary to take some rehabilitating actions in realm of environment which means we can use more green and environmental products, especially in realm of transportation and vehicles. In addition, it also can cover international country's role in order to achieve the environmental objectives such as reducing the emission of greenhouse gases and declining the global warming phenomenon. In general, in order to address all of these discussed problems, investing on green vehicles (Electric/Hybrid vehicles) it seems to be an appropriate strategy. Analyzing the more compatible green vehicles and finally prioritizing the best cases, suitable with Iran community is the objective of this paper.

\section{LITERATURE}

\section{GREEN VEHICLES}

The term of "green" is defined literally as an adjective, equivalents to what is liked and protected by nature, or minimizes damage to the environment (LONGMAN ADVANCED AMARICAN DICTIONARY, 2013). Green technology means the use of methods and approaches that can increase the energy efficiency (in realm of consumption), also manufactures products with the lowest levels of pollution (toxic substances) (www.green-technology.org/). Green cars include vehicles that reduce energy consumption and reduce pollutant emissions. Hybrid / electric cars are considered as green cars with high efficiency and high energy consumption and reduced air pollution. Sale rate of this sort of cars rose by $70 \%$ from 2014 to 2015 (LI et al, 2016).

\section{RESEARCH BACKGROUND}

Almost all of the researches that have been done in realm of green vehicles, have admitted the necessity of replacing the regular vehicles with Electric/Hybrid ones. They mostly have accounted the economic, social and environmental benefits of using more green cars. In addition, scientific scholars have mentioned some challenges of this process. We will review some of this articles and their important aspects in following paragraph.

Onn et al (2017) emphasized on the urge of using green cars to reduce the level of the local pollution and also reduce greenhouse gases emission (related to global warming). They claimed that prevalence of using green cars has been affected by the weakness of the private sector and the lack of 
appropriate infrastructure, something that strongly needs governments' supports. Winyuchakrit et al (2017) stated that the using of electric / hybrid vehicles can reduce energy consumption and increase efficiency of fuel in the transportation sector, therefore local and national plans and projects (case study Thailand and also all developing countries) should move toward supporting such green cars. Wang et al. (2017) emphasized on the role of government in providing financial motivations before buying (tax exemptions, loan and installment buying) would rather be more effective in choosing and purchasing electric vehicles by households than after-purchase facilities (such as placing tax and transit fees and parking fee on regular cars). Lévay et al (2017) claimed that the reduction in the final purchase price (equivalent to domestic manufacturing price) as an important factor in encouraging citizens to buy electric cars. The experiences of some countries such as Norway, France and the United Kingdom admit this claim. Hi and Zhan (2018) urging the sense of responsibility (about the environmental) as a moral dilemma (among people and authorities) to replace regular cars with electric / hybrid cars is the most crucial aspect of any replacement plan. Adnan et al (2017) have placed an important role on environmental- economic practice of using Hybrid/Electric vehicles in Malaysia's development. In this regard, the social trends in the selection of vehicles by households most be regarded as the significant factor (people's car taste) after which government should pay attention on providing infrastructure for electric/hybrid vehicles. Bellekom et al (2012) mentioned the Dutch pioneering plans 1 to replace fossil cars with hybrid / electric vehicles, they suggest using wind power (due to the fact that wind turbines are unanimous in this country) for generating electricity for green vehicles as a whole green process. Bahrami et al (2017) considered the necessity of replacing of gasoline vehicles with electric ones, but they also focused on providing required infrastructure (charging station) as an crucial aspect of this plan that should not be neglected, because without providing that sort of infrastructure some great benefits might be lose. Peng et al (2017) have compared electric vehicles (with hybrid ones) and concluded that the use of electric vehicles in the long term which is more compatible with environmental and economic objectives and the future of the car market belongs to all-electric vehicles.

\section{ELECTRIC VEHICLES AND INTERNATIONAL TRENDS}

In general, cars can be divided into three groups: cars with internal combustion engines, electric hybrid vehicles and all-electric vehicles (BOROOJENI et al, 2016). The emerging of electric vehicles in the third millennium is considered as the one of the latest innovations in the automotive 
industry. The Toyota Prius was originally produced in early 2000 as the world's first electric vehicle (electric / gasoline). There are significant benefits toward the electric vehicle (compared to conventional gasoline vehicles). The low emission and greenhouse gas, high energy efficiency and possibility of using renewable energy sources (such as solar energy) have turned electric vehicles into a new option for the transportation industry in the new millennium (Adnan et al 2017). Due to the benefits that are contributed to this sort of cars such as increasing the fuel efficiency, reducing fuel consumption and the environmental benefits associated with this vehicles, using of these electric vehicles in Europe, the United States and Japan has gained popularity (Fotouhi et al, 2016). In 2016, the market of the electric vehicles was equivalent to 750000 cars (the vehicles which were produced by 78 major car manufacturers). The share of different countries in this market is not equal. The largest shares of Electric vehicles market is contributed to China1 by $40 \%$ and the United States by $20 \%$ of the whole electric vehicle market. Norwegian (29\%), Netherlands (6.4\%), Sweden (3.4\%), France, and the United Kingdom (each by 1.5\%) have the other shares of this market (GLOBAL EV OUTLOOK, 2017).

However, the popularity of this kind of vehicles is not exclusively related to the developed country, when in 2012, the Malaysian2 government planned on using 500 thousand and 5 million electric cars respectively in 2015 and 2020 on the roads of this country (The National Council of Malaysia, 2012). According to the World Bank (2017), in 2024, the cost of purchasing an electric vehicle would be equivalent to the cost of a conventional gasoline car. So, it is worth noting that the electric car will cover all the capabilities of gasoline vehicles. By 2030, $60 \%$ of EU vehicles will be electrical. By 2040, electric cars will account for $45 \%$ of whole car market. However, there are still some problem about performance and capability of Electric vehicles, among which relatively lower maneuvering power of EVs versus petrol cars (passing by downhill, lower acceleration), time consuming battery charging are the most significant problems contributed to electric cars, but due to the new innovation in car industry it is expected they will be solved in midterm (TENG et al, 2017).

In conclusion, due to the significant capabilities of electric vehicles, global trends, countries' investment in this area, the automobile factories' interest toward producing the electric vehicles, widespread use of these cars is highly expected. Therefore, designing a national program, attracting the participation of various sectors of society in the area of production and using these cars will be considered as a step toward a sustainable future in economic, social and environmental realms.

1 China in 2016 was the largest EV market with 200 million electric motorcycles, 300000 electric buses, and 3 to 4 million low-speed electric vehicles.

2 Malaysian government has invested \$ 16 billion dollars in technology of manufacturing electric vehicles for five years and has introduced special exemptions and facilities for production of these vehicles (Sang and Bekhet, 2015) 


\section{METHODOLOGY}

This study adopts a descriptive-analytic method, the survey community is included all experts in the field of environmental management, sample size is obtained using non-random objective method (10 experts, which were university professors in the field of management, have been questioned) for prioritizing between different cars based on an analytic hierarchy process. Research validity was confirmed by professors of management. In order to measure the level of reliability, Inconsistency index 1 (equal to 0) was used and it turned out that the data is reliable. $\mathrm{An} \mathrm{AHP}_{2}$ model was expanded for obtaining the goals of the research. Based on the method that was designed, there was three levels in the model. The first level is goal, which is defined as a selecting the most compatible Electric/Hybrid vehicle with Iran society, the second level was included the indicators that were important in choosing an Electric/Hybrid vehicle, which were twelve cases including price, level of released greenhouse gas, noise pollution, energy consumption, passed distance by each charge, speed, acceleration, safety, infrastructure, the time needed for being fully charged, attractiveness, and passenger capacity. At the third level we have presented 4 Electric/Hybrid vehicles as the alternatives of research which should be prioritized based on the twelve factors mentioned in previous level (level 2). This 4 special cars were chosen based on their selling rate (the best seller were selected) and popularity. The cars were include: FORD2018 C-MAX HYBRID SE, TOYOTA 2018 PRIUS One, which were Hybrid, and C-MAX HYBRID SE MITSUBISHI 2017, KIA 2017 SOUL EV, which were electrical.

In this part, 14 important features of four types of green cars (Electric/Hybrid Vehicles) was presented. Actually, having this sort of data is necessary for prioritizing best case for replacing with regular cars in Iran. These cars are including two fully-electric vehicles and two hybrid vehicles. In the following table, each car's specifications were resented based on 14 elements. The data which is related to each case has been extracted from the car factories' websites.

1 We can claim that a test (or statistical test) is reliable when Inconsistency index rate is lower than 0.05 , which was obtained from Expert Choice software.

2 The Analytic Hierarchy Process (AHP), introduced by Thomas Saaty (1980), is an effective tool for dealing with complex decision making, and may aid the decision maker to set priorities and make the best decision. By reducing complex decisions to a series of pairwise comparisons, and then synthesizing the results, the AHP helps to capture both subjective and objective aspects of a decision. In addition, the AHP incorporates a useful technique for checking the consistency of the decision maker's evaluations, thus reducing the bias in the decision making process.

The AHP can be implemented in three simple consecutive steps:

1 Computing the vector of criteria weights.

2 Computing the matrix of option scores.

3 Ranking the options (Saaty, 1980). 
Figure 1: Conceptual model (based on three AHP levels)

Selecting the Most Compatible Green

(Electric/Hybrid) Vehicle with Iran Society

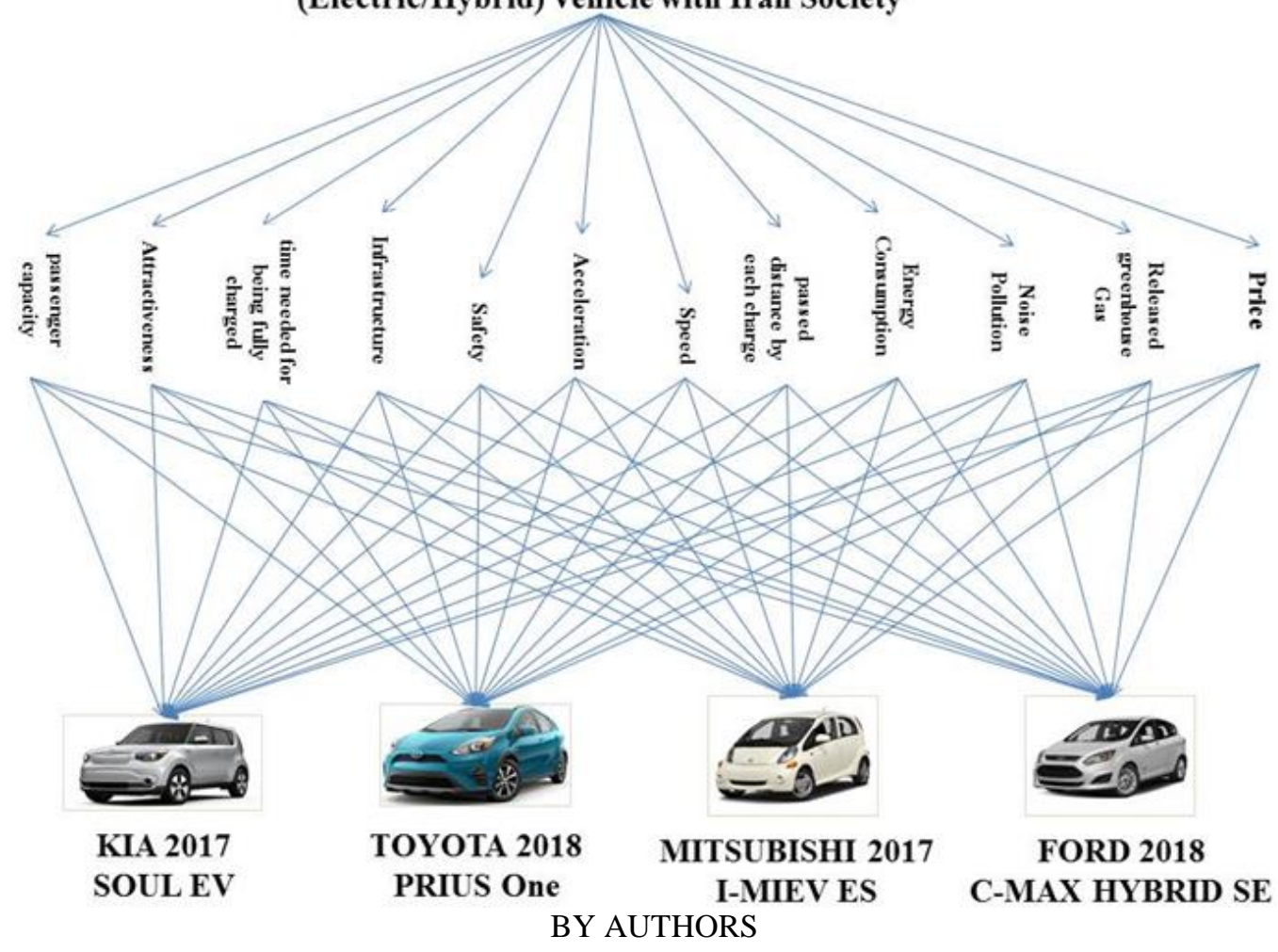

Table 2: Forty basic features of four selected "Green Vehicles" models

\begin{tabular}{|c|c|c|c|c|}
\hline \multirow[t]{2}{*}{ Models } & & & & \\
\hline & $\begin{array}{l}\text { KIA } 2017 \\
\text { SOUL EV }\end{array}$ & $\begin{array}{l}\text { TOYOTA } 2018 \\
\text { PRIUS One }\end{array}$ & $\begin{array}{l}\text { MITSUBISHI } \\
2017 \\
\text { I-MIEV ES } \\
\end{array}$ & $\begin{array}{c}\text { 2018FORD } \\
\text { C-MAX HYBRID } \\
\text { SE }\end{array}$ \\
\hline Fuel/energy & Electricity & $\begin{array}{c}\text { Hybrid } \\
\text { (electricity/gasoline) }\end{array}$ & Electricity & $\begin{array}{c}\text { Hybrid } \\
\text { (electricity/gasoline) }\end{array}$ \\
\hline Price1 & 32250 & 23475 & 22995 & 24120 \\
\hline $\begin{array}{c}\text { Maximum } \\
\text { Speed )KM/H( }\end{array}$ & 145 & 180 & 129 & 186 \\
\hline $\begin{array}{l}\text { Acceleration }(0 \\
\text { to } 100 \mathrm{~km} / \mathrm{h})\end{array}$ & 11.2 seconds & 10.6 seconds & 15.6 seconds & 8.7 seconds \\
\hline $\begin{array}{c}\text { Fuel/energy } \\
\text { Consumption2 }\end{array}$ & 1.96 & 3.6 & 1.94 & 5.9 \\
\hline Released & 0 & 49 & 0 & 76 \\
\hline
\end{tabular}




\begin{tabular}{|c|c|c|c|c|}
\hline \multirow[t]{2}{*}{ Models } & & & & \\
\hline & $\begin{array}{l}\text { KIA } 2017 \\
\text { SOUL EV }\end{array}$ & $\begin{array}{l}\text { TOYOTA } 2018 \\
\text { PRIUS One }\end{array}$ & $\begin{array}{l}\text { MITSUBISHI } \\
2017 \\
\text { I-MIEV ES } \\
\end{array}$ & $\begin{array}{c}\text { 2018FORD } \\
\text { C-MAX HYBRID } \\
\text { SE }\end{array}$ \\
\hline \multicolumn{5}{|l|}{ pollution1 } \\
\hline $\begin{array}{l}\text { Released noise } \\
\text { pollution2 }\end{array}$ & 38 & 69 & 42 & 72 \\
\hline $\begin{array}{l}\text { The time } \\
\text { needed for } \\
\text { being fully } \\
\text { charged }\end{array}$ & $\begin{array}{c}12 \\
\text { hours(domestic } \\
\text { outlet) } 2.3 \mathrm{KW} \\
\text { (enough for } \\
\text { traveling a } \\
\text { distance equal to } \\
100 \mathrm{~km} \text { ) }\end{array}$ & $\begin{array}{l}5.5 \text { hours(domestic } \\
\text { outlet) } 2.3 \mathrm{KW} \\
\text { (enough for } \\
\text { traveling a distance } \\
\text { equal to } 40.2 \mathrm{~km} \text { ) }\end{array}$ & $\begin{array}{c}14 \\
\text { hours(domestic } \\
\text { outlet) } 2.3 \mathrm{KW} \\
\text { (enough for } \\
\text { traveling a } \\
\text { distance equal } \\
\text { to } 222 \mathrm{~km} \text { ) }\end{array}$ & $\begin{array}{l}6 \text { hours(domestic } \\
\text { outlet) } 2.3 \mathrm{KW} \\
\text { (enough for } \\
\text { traveling a distance } \\
\text { equal to } 23 \mathrm{~km} \text { ) }\end{array}$ \\
\hline Infrastructure & $\begin{array}{c}\text { Domestic } \\
\text { electricity- } \\
\text { charging stations }\end{array}$ & $\begin{array}{c}\text { Domestic } \\
\text { electricity-charging } \\
\text { stations }\end{array}$ & $\begin{array}{l}\text { Domestic } \\
\text { electricity- } \\
\text { charging } \\
\text { stations }\end{array}$ & $\begin{array}{c}\text { Domestic } \\
\text { electricity-charging } \\
\text { stations }\end{array}$ \\
\hline Guarantee & $\begin{array}{l}60 \text { months } \\
\text { equivalent of } 60 \\
\text { thousand miles }\end{array}$ & $\begin{array}{l}36 \text { months } \\
\text { equivalent of } 36 \\
\text { thousand miles }\end{array}$ & $\begin{array}{l}36 \text { months } \\
\text { equivalent of } 36 \\
\text { thousand miles }\end{array}$ & $\begin{array}{l}36 \text { months } \\
\text { equivalent of } 36 \\
\text { thousand miles }\end{array}$ \\
\hline Safety3 & 4 & 4 & 4 & 4 \\
\hline Height & 63 & 58.1 & 63.6 & 63.9 \\
\hline $\begin{array}{l}\text { Passenger } \\
\text { Capacity }\end{array}$ & 5 & 5 & 4 & 5 \\
\hline $\begin{array}{c}\text { Cargo } \\
\text { Capacity4 }\end{array}$ & 18.8 & 24.6 & 13.2 & 24.5 \\
\hline
\end{tabular}

Reference: KIA, TOYOTA, MITSUBISHI and FORD websites

\section{RESULTS AND DISCUSSION}

After describing the necessity of using green vehicles(related to environmental issues and their health and economic costs which are contributed to air pollution) it is clear that Electric/Hybrid cars would be considered as one of the best option to step in sustainability way, but still there is a question, which case and which features are the best and most important ones, due to the local situation,

1 Based on the $\mathrm{CO}_{2}$ pollutant,unit in grams per mile, it is worthy to mentioning that PM10 and PM2.5 amounts are zero for the four models. Also, the $\mathrm{CO}_{2}$ emissions mentioned for hybrid cars are in the mode of using the gasoline engine, and they do not produce any $\mathrm{CO}_{2}$ pollution when they use electric motors.

2 Based on the decibel unit, the human hearing range is between 0 and 120 calories.

3 Based on the safety index defined by the US Highway Safety Administration, the defined scale has a range from 1 to 5 that takes aome important satefty features into account (https://www.nhtsa.gov/ ratings).

4 The scale defined as the "cu.ft" includes a set of dimensions, length, width, and height (http://www.ginifab.com/feeds/cbm/cbm_caluclator_inch_lb.html). 
something that we asked from the experts of this realm(figure 2 is included the: Hierarchy tree of research). Based on the research methodology 10 experts were questioned (comparative method between different cases), the average of the marked which were specified to each case has calculated and entered in Expert choice software. Two step of this process explained in following paragraphs.

Figure 2: Hierarchy tree designed for selecting the most compatible Green vehicle with Iran society in Expert Choice 11 software

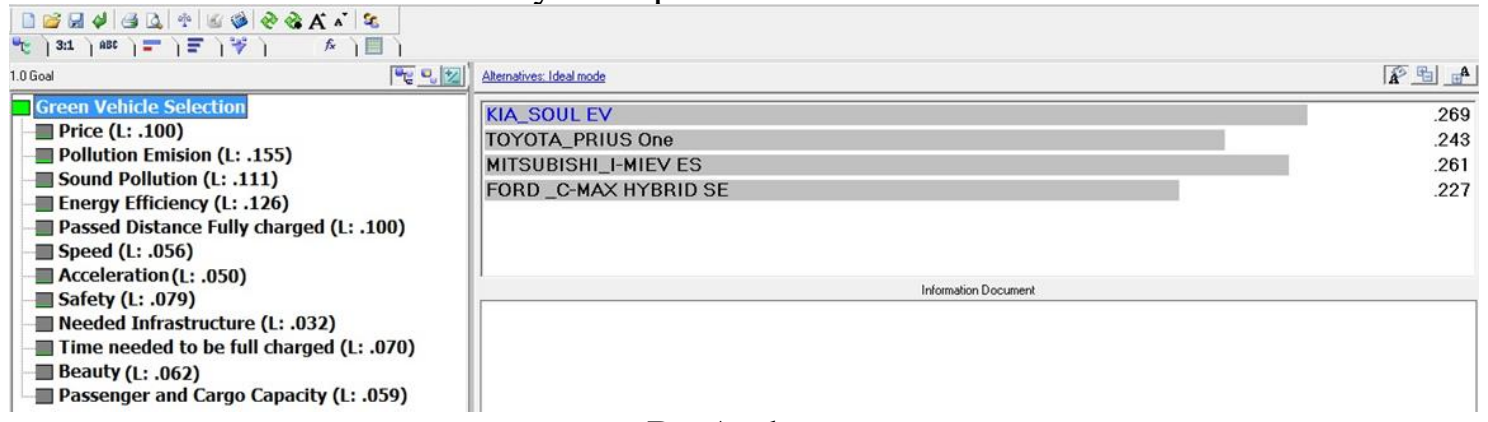

By Authors

\section{COMPARISON BETWEEN 12 INDICATORS AND FOUR CARS}

The most significant features of Green Vehicles (four chosen case) organized into 12 indicators and experts were asked to compare the importance of each case with other ones. Based on the average of the scores that have been specified to each indicator, the importance and rank of each indicator has been calculated (It is important to know that experts were presented the significant features of each car, therefore they were completely aware of all environmental and economic aspects of the cars, they also were expected to score the cars based on their social dimensions of Iranian society). It is clear that based on expert perspectives releasing the least amount of air pollution was the most important feature of each car (rank one for this factor, MITSUBISHI I-MIEV ES gained the best rank based on this factor).

The rank two was Fuel/energy Consumption which is a combination of economic and environmental factor (KIA SOUL EV had the best performance in this group). Noise pollution, which is a crucial issue in urban areas has gained the third rank (KIA SOUL EV was the best one in this group). Fourth factor with highest score was price, which is really important for families especially for middle class to afford this kind of cars (the most affordable car was MITSUBISHI I-MIEV ES). The traveled distance with each full charge, is the fifth important factor, which can affect the comfrotability of using green cars (MITSUBISHI I-MIEV ES was the best case in this group). Sixth important factor was safety, all of the cases have gained the same rank in this group. It is crucial to pass the most possible distance with each charge, therefore this factor was gained the seventh rank 
(TOYOTA PRIUS One was the best one). Acceleration is the eighth important factor (the best one in this group was FORD C-MAX HYBRID SE).

Other factors which gained ninth to twelve ranks were included passenger and cargo capacity, speed, infrastructure, attractiveness respectively. The low score for the ninth indicator can be attributed to statistical family trends in Iranian society1, speed is not that much crucial because all of the four cars can meet the maximum permitted speed in Iran2, infrastructure is not that much important (eleventh factor) because still there is no Green Vehicle infrastructure in Iran, therefore all of the cars are equal for this factor. Twelfth factor is attractiveness which is highly diverse and it cannot be judged base on the experts' ideas.

Table 3. Weight and rank of each indicator and alternative

\begin{tabular}{|c|c|c|c|c|c|c|}
\hline \multirow{2}{*}{ Number } & \multicolumn{3}{|c|}{ Indicator } & \multicolumn{3}{|c|}{ Alternative } \\
\hline & Indicator & weight & Rank & Alternative & weight & Rank \\
\hline \multirow{4}{*}{1} & \multirow{4}{*}{ Price } & \multirow{4}{*}{4} & \multirow{4}{*}{0.1} & KIA SOUL EV & 0.236 & 4 \\
\hline & & & & TOYOTA PRIUS One & 0.252 & 2 \\
\hline & & & & $\begin{array}{l}\text { MITSUBISHI I-MIEV } \\
\text { ES }\end{array}$ & 0.268 & 1 \\
\hline & & & & $\begin{array}{c}\text { FORD C-MAX } \\
\text { HYBRID SE }\end{array}$ & 0.244 & 3 \\
\hline \multirow{4}{*}{2} & \multirow{4}{*}{$\begin{array}{l}\text { Released air } \\
\text { pollution }\end{array}$} & \multirow{4}{*}{1} & \multirow{4}{*}{0.155} & KIA SOUL EV & 0.348 & 1 \\
\hline & & & & TOYOTA PRIUS One & 0.168 & 3 \\
\hline & & & & $\begin{array}{l}\text { MITSUBISHI I-MIEV } \\
\text { ES }\end{array}$ & 0.348 & 2 \\
\hline & & & & $\begin{array}{c}\text { FORD C-MAX } \\
\text { HYBRID SE }\end{array}$ & 0.136 & 4 \\
\hline \multirow{4}{*}{3} & \multirow{4}{*}{ Noise pollution } & \multirow{4}{*}{3} & \multirow{4}{*}{0.111} & KIA SOUL EV & 0.275 & 1 \\
\hline & & & & TOYOTA PRIUS One & 0.243 & 3 \\
\hline & & & & $\begin{array}{l}\text { MITSUBISHI I-MIEV } \\
\text { ES }\end{array}$ & 0.258 & 2 \\
\hline & & & & $\begin{array}{c}\text { FORD C-MAX } \\
\text { HYBRID SE }\end{array}$ & 0.255 & 4 \\
\hline \multirow{4}{*}{4} & \multirow{4}{*}{$\begin{array}{l}\text { Fuel/energy } \\
\text { Consumption }\end{array}$} & \multirow{4}{*}{2} & \multirow{4}{*}{0.126} & KIA SOUL EV & 0.297 & 1 \\
\hline & & & & TOYOTA PRIUS One & 0.244 & 3 \\
\hline & & & & $\begin{array}{l}\text { MITSUBISHI I-MIEV } \\
\text { ES }\end{array}$ & 0.297 & 2 \\
\hline & & & & $\begin{array}{c}\text { FORD C-MAX } \\
\text { HYBRID SE }\end{array}$ & 0.183 & 4 \\
\hline \multirow{4}{*}{5} & \multirow{4}{*}{$\begin{array}{l}\text { The traveled } \\
\text { distance with } \\
\text { each full charge }\end{array}$} & \multirow{4}{*}{5} & \multirow{4}{*}{0.1} & KIA SOUL EV & 0.26 & 2 \\
\hline & & & & TOYOTA PRIUS One & 0.24 & 3 \\
\hline & & & & $\begin{array}{c}\text { MITSUBISHI I-MIEV } \\
\text { ES }\end{array}$ & 0.281 & 1 \\
\hline & & & & FORD C-MAX & 0.219 & 4 \\
\hline
\end{tabular}




\begin{tabular}{|c|c|c|c|c|c|c|}
\hline \multirow{3}{*}{ Number } & \multicolumn{3}{|c|}{ Indicator } & \multicolumn{3}{|c|}{ Alternative } \\
\hline & Indicator & weight & Rank & Alternative & weight & Rank \\
\hline & & & & HYBRID SE & & \\
\hline \multirow{4}{*}{6} & \multirow{4}{*}{ Speed } & \multirow{4}{*}{10} & \multirow{4}{*}{0.056} & KIA SOUL EV & 0.235 & 3 \\
\hline & & & & TOYOTA PRIUS One & 0.266 & 2 \\
\hline & & & & $\begin{array}{l}\text { MITSUBISHI I-MIEV } \\
\text { ES }\end{array}$ & 0.244 & 4 \\
\hline & & & & $\begin{array}{c}\text { FORD C-MAX } \\
\text { HYBRID SE }\end{array}$ & 0.285 & 1 \\
\hline \multirow{4}{*}{7} & \multirow{4}{*}{ Acceleration } & \multirow{4}{*}{8} & \multirow{4}{*}{0.062} & KIA SOUL EV & 0.251 & 3 \\
\hline & & & & TOYOTA PRIUS One & 0.263 & 2 \\
\hline & & & & $\begin{array}{l}\text { MITSUBISHI I-MIEV } \\
\text { ES }\end{array}$ & 0.205 & 4 \\
\hline & & & & $\begin{array}{c}\text { FORD C-MAX } \\
\text { HYBRID SE }\end{array}$ & 0.281 & 1 \\
\hline \multirow{4}{*}{8} & \multirow{4}{*}{ Safety } & \multirow{4}{*}{6} & \multirow{4}{*}{0.079} & KIA SOUL EV & 0.25 & - \\
\hline & & & & TOYOTA PRIUS One & 0.25 & - \\
\hline & & & & $\begin{array}{l}\text { MITSUBISHI I-MIEV } \\
\text { ES }\end{array}$ & 0.25 & - \\
\hline & & & & $\begin{array}{c}\text { FORD C-MAX } \\
\text { HYBRID SE }\end{array}$ & 0.25 & - \\
\hline \multirow{4}{*}{9} & \multirow{4}{*}{ Infrastructure } & \multirow{4}{*}{11} & \multirow{4}{*}{0.05} & KIA SOUL EV & 0.203 & 4 \\
\hline & & & & TOYOTA PRIUS One & 0.297 & 1 \\
\hline & & & & $\begin{array}{l}\text { MITSUBISHI I-MIEV } \\
\text { ES }\end{array}$ & 0.203 & 3 \\
\hline & & & & $\begin{array}{c}\text { FORD C-MAX } \\
\text { HYBRID SE }\end{array}$ & 0.297 & 2 \\
\hline \multirow{4}{*}{10} & \multirow{4}{*}{$\begin{array}{l}\text { The time } \\
\text { needed for } \\
\text { being fully } \\
\text { charged }\end{array}$} & \multirow{4}{*}{7} & \multirow{4}{*}{0.07} & KIA SOUL EV & 0.228 & 3 \\
\hline & & & & TOYOTA PRIUS One & 0.291 & 1 \\
\hline & & & & $\begin{array}{l}\text { MITSUBISHI I-MIEV } \\
\text { ES }\end{array}$ & 0.205 & 4 \\
\hline & & & & $\begin{array}{c}\text { FORD C-MAX } \\
\text { HYBRID SE }\end{array}$ & 0.276 & 2 \\
\hline \multirow{4}{*}{11} & \multirow{4}{*}{ Attractiveness } & \multirow{4}{*}{12} & \multirow{4}{*}{0.032} & KIA SOUL EV & 0.295 & 1 \\
\hline & & & & TOYOTA PRIUS One & 0.266 & 2 \\
\hline & & & & $\begin{array}{c}\text { MITSUBISHI I-MIEV } \\
\text { ES }\end{array}$ & 0.209 & 4 \\
\hline & & & & $\begin{array}{c}\text { FORD C-MAX } \\
\text { HYBRID SE }\end{array}$ & 0.23 & 3 \\
\hline \multirow{4}{*}{12} & \multirow{4}{*}{$\begin{array}{l}\text { Passenger and } \\
\text { cargo capacity }\end{array}$} & \multirow{4}{*}{9} & & KIA SOUL EV & 0.238 & 3 \\
\hline & & & & TOYOTA PRIUS One & 0.28 & 1 \\
\hline & & & 0.059 & $\begin{array}{l}\text { MITSUBISHI I-MIEV } \\
\text { ES }\end{array}$ & 0.224 & 4 \\
\hline & & & & $\begin{array}{c}\text { FORD C-MAX } \\
\text { HYBRID SE }\end{array}$ & 0.259 & 2 \\
\hline
\end{tabular}

By Authors 
As we explained in previous part, 12 indicators have gained specific marks and ranks, also each car was compared with other ones based on each indicators. At this level the scores contributed to each indicator applied on the score of each car and final scores of cars was calculated. Base on the obtained results, prevalence of environmental perspective caused that both of fully electric cars (KIA SOUL EV and MITSUBISHI I-MIEV ES) gained the first and second ranks. TOYOTA PRIUS One and FORD C-MAX HYBRID SE as the two hybrid cars gained the third and fourth ranks.

Table 4: Final weights and ranks of alternatives

\begin{tabular}{ccc}
\hline Rank & Equivalent Weight & Alternative \\
\hline 1 & 0.269 & KIA SOUL EV \\
3 & 0.243 & TOYOTA PRIUS One \\
2 & 0.261 & MITSUBISHI I-MIEV ES \\
4 & 0.227 & FORD C-MAX HYBRID SE \\
\hline \multicolumn{2}{c}{ By Authors }
\end{tabular}

Figure 3: Final weights and ranks of alternatives

Overall Inconsistency $=.00$

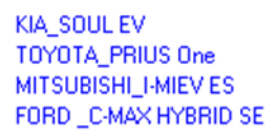

FORD_C-MAX

\section{CONCLUSIONS}

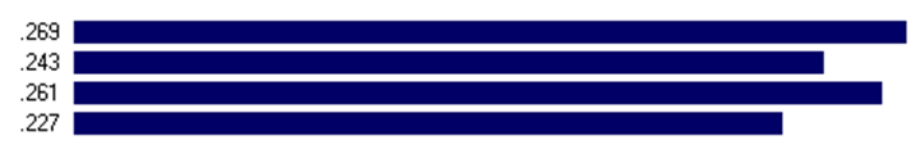

By Authors

As we mentioned, a great deal of environmental pollution (especially air and noise pollution) is contributed to transportation sector, which casts nations a lot in different realms such as human health care and economy. Therefore, it is really necessary to make some plans which can increase the efficiency of fuel consumption and decrease the level of pollution and its devastating effects. Using Green Vehicles, which has gained a significant popularity in transportation sector, is one of the innovative environmental approaches that has been applied in different parts of the world. However, due to the fact that level of development, infrastructure, economic status, cultures and demographic situations are different in different parts of the world, it is crucial to make plans based on the dimensions of target country. In fact, no sooner had we made a practical plan than we have known all of the aspects a society that we want to intervene.

Such perspective was the basic approach this paper, in order achieve this goal we have described the devastating aspects of using out of date technology in transportation sector and necessity of replacing green vehicles in it. In continue, we have recognized the most significant aspects and advantages (12 indicators) of using Hybrid/Electric vehicles (as the green cars) and also chosen four cars ( 2 Hybrid and 2 fully electric cars). In order to prioritize the indicators and cars 
(based on the 12 indicators) knowledge of experts a professional people (in the fields of management and environment science) was applied (using Analytic Hierarchy Process and comparative method).

Based on the results of the research it was clear that environmental aspects of Green Vehicles were the most significant advantages of them because based on the importance weight which were specified to the indicators some aspects such as released air pollution, fuel/energy consumption, Noise pollution contributed to each car, have gained the highest level of importance. Other economic aspects (such as price, and the traveled distance with each full charge) and professional aspects (such as safety, and the time needed for being fully charged) have gained other superiorities. Each car (based on its performance) has gained different ranks, but in general fully eclectic cars have gained the first rank (in comparison with Hybrid cars). We can conclude from this result that due to the latest technology trend in automobile industry, fully electric cars are the future of this industry and it is worthy enough for government (even in developing countries such as Iran) to invest in this realm.

The result of this research is matched with some previous studies, among which we can mention' Ednan et al. (2017) which declared that all-electric vehicles are the best cases to be replaced with regular cars in transportation sector in Malaysia in order to reduce the emission of pollutants and gain environmental and economic benefits." Also, the results of "Peng et al. (2017) which claimed that electric are the future of the automobile industry, and government (chines government) should invest in this realm."

Finally, this research has tried to use an integrated approach which can consider almost all global and technological trends in realm of Green Vehicles, and also notice local challenges (environmental issues contributed to transportation sectors) and organize all aspects in a way that can provide the country with a high efficient transportation system (related to automobiles). Using the green Vehicles (as we resulted and proposed the Electric cars) all stockholders of transportation sector can be benefited equally and efficiently.

\section{REFERENCES}

ADNAN, N., NORDIN, S. M., \& RAHMAN, I \& RASLI, A. M. A new era of sustainable transport: An experimental examination on forecasting adoption behavior of EVs among Malaysian consumer.

Transportation Research Part A: Policy and Practice, 103, 279-295.2017.

ADNAN, N., NORDIN, S. M., \& RAHMAN, I. Adoption of PHEV/EV in Malaysia: A critical review on predicting consumer behaviour. Renewable and Sustainable Energy Reviews, 72, 849-862. 2017.

BAHRAMI, S., ASHTIANI, H. Z., NOURINEJAD, M., \& ROORDA, M. J. A complementarity equilibrium model for electric vehicles with charging. International Journal of Transportation Science and Technology, 6(4), 255-271. 2017.

BATTISTA, G. Analysis of the Air Pollution Sources in the city of Rome (Italy). Energy Procedia 126: 392-397.2017.

BELLEKOM, S., BENDERS, R., PELEGROM, S., \& MOLL, H. Electric cars and wind energy: Two problems, one solution? A study to combine wind energy and electric cars in 2020 in The Netherlands. 
Energy, 45(1), 859-866.2012.

BORROJENI, K.G., AMINI, M.H., BAHRAMI,. A novel multi-time-scale modeling for electric power demand forecasting: from short-term to medium-term horizon. Elect. Power Syst. Res. 142, 58-73.2017

Energy Balance Sheet (2016) Deputy Director General for Electricity and Energy Affairs Office of Planning for Electricity and Energy.

EVI (2016), United States submission for the EVI “Global EV outlook 2016" (internal document). FALAHATI.A. new smart charging method for EVs for frequency control of smart grid. International Journal of Electrical Power \& Energy Systems 83: 458-469.2016.

FOTOUHI, A., AUGER, D.J., PROPP, K. A review on electric vehicle battery modelling: from Lithium-ion toward Lithium-Sulphur .Renew. Sustain. Energy Rev. 56, 1008-1021.2016.

HE, X., \& ZHAN, W. How to activate moral norm to adopt electric vehicles in China? An empirical study based on extended norm activation theory. Journal of Cleaner Production, 172, 3546-3556. 2018.

HUANG, L., ZHOU, L., CHEN, J., CHEN, K., LIU, Y., CHEN, X., \& TANG, F. Acute effects of air pollution on influenza-like illness in Nanjing, China: A population-based study. Chemosphere, 147, 180-187. 2016.

LEVAY, P. Z., DROSSINOS, Y., \& THIEL, C. The effect of fiscal incentives on market penetration of electric vehicles: A pairwise comparison of total cost of ownership. Energy Policy, 105, 524-533. 2017.

LI, S., TONG, L., XING, J. and ZHOU, Y. The Market for Electric Vehicles: Indirect Network Effects and Policy Design (May 2016). Available at SSRN: http://ssrn.com/abstract=2515037 or http://dx.doi.org/10.2139/ssrn.2515037,2016.

Longman Advanced Amarican Dictionary. Publisher: Allyn \& Bacon; 3rd Revised ed. edition (Sept. 27 2013).

ONN, C. C., MOHD, N. S., YUEN, C. W., LOO, S. C., KOTING, S., ABD RASHID, A. F.,... YUSOFF, S. Greenhouse gas emissions associated with electric vehicle charging: The impact of electricity generation mix in a developing country. Transportation Research Part D: Transport and Environment.2017.

PENG, T., OU, X., \& YAN, X. Development and application of an electric vehicles life-cycle energy consumption and greenhouse gas emissions analysis model. Chemical Engineering Research and Design. 2017.

ROMERO-RUIZ, J. Probabilistic congestion management using EVs in a smart grid with intermittent renewable generation. Electric Power Systems Research 137: 155-162.2016.

SAATY, Thomas L. The Analytic Hierarchy Process.” McGraw-Hill, New York.1980.

SAATY, Thomas L. Relative Measurement and its Generalization in Decision Making: Why Pairwise Comparisons are Central in Mathematics for the Measurement of Intangible Factors - The Analytic Hierarchy/Network Process" (http://www.rac.es/ficheros/doc/576.PDF).2008.

SANG, Y.-N., BEKHET, H.A. Modelling electric vehicle usage intentions: an empirical study in Malaysia. J. Clean. Prod. 92, 75-83.2015.

SARKHOSH, M., MAHVI, A.H., YUNESIAN, M. Source Apportionment of Volatile Organic Compounds in Tehran, Iran. Bull Environ Contam Toxicol, 2013.

TENG, F., MU, Y., JIA, H., WU, J., ZENG, P., \& STRBAC, G. Challenges on primary frequency control and potential solution from EVs in the future GB electricity system. Applied Energy, 194, 353-362. 2017.

WANG, N., TANG, L., \& PAN, H. Effectiveness of policy incentives on electric vehicle acceptance in China: A discrete choice analysis. Transportation Research Part A: Policy and Practice, 105, 210218. 2017.

WINYUCHAKRIT, P., SUKAMONGKOL, Y., \& LIMMEECHOKCHAI, B. Do Electric Vehicles Really Reduce GHG Emissions in Thailand? Energy Procedia, 138, 348-353. 2017.

WORLD HEALTH ORGANIZATION. Air Quality Guidelines: Global Update 2015: Particulate 
Matter, Ozone, Nitrogen Dioxide, and Sulfur Dioxide, World Health Organization, 2015.

WORLD BANK .The Cost of Air Pollution: Strengthening the Economic Case for Action. Washington, D.C,. World Bank Group, 2016.

WORLD BANK GROUP. Iranian Economic Observer (toward Reunification), Department of Global Studies in Macroeconomics and Financial Management of the Middle East and North Africa, Washington, DC 20433.2016.

https:// www.amar.org

https://www.kia.com/us/en/vehicle/soul-ev/2017/compare

https://www.doe.ir/Portal/home

https://www.mitsubishicars.com/outlander/2017/features/safety-and-warranty\#forward-collisionmitigation

https://www.toyota.com/prius/

https://www.ford.com/cars/c-max/models/c-max-hybrid-se/

https://financialtribune.com/articles/environment/76232/iran-greenhouse-gas-emissions-up-3-indecade

https://unfccc.int/sites/default/files/resource/PA_Progress\%20tracker\%2020\%20apr_rev.pdf 